Jurnal Perikanan (2020) Volume 10. No. $1: 29-40$

DOI : https://doi.org/10.29303/jp.v10i1.177

\title{
PENGARUH KONSENTRASI NIRA AREN (Arenga pinnata) TERHADAP SINTASAN DAN PERTUMBUHAN LARVA IKAN BANDENG (Chanos chanos Forskal)
}

\section{THE EFFECT OF SAP CONCENTRATION OF ARENG PALM (Arenga pinnata) ON SURVIVAL AND GROWTH OF MILKFISH (Chanos chanos Forskal) LARVAE}

\author{
Diaz Asa Gusmi ${ }^{*}$, Nanda Diniarti, Alis Mukhlis \\ ${ }^{1)}$ Program Studi Budidaya Perairan, Universitas Mataram \\ *)alamat korespondensi: diazasagusmi18@gmail.com
}

\begin{abstract}
Abstrak
Penelitian ini bertujuan untuk mengetahui pengaruh konsentrasi nira aren (Arenga pinnata) terhadap sintasan dan pertumbuhan larva ikan bandeng (Chanos chanos Forskal) dan mendapatkan konsentrasi nira terbaik untuk sintasan dan pertumbuhan larva ikan bandeng. Penelitian menggunakan metode eksperimen yang dirancang menggunakan Rancangan Acak Lengkap (RAL) terdiri atas empat perlakuan yang diulang sebanyak tiga kali ulangan. Perlakuan yang diuji yaitu penambahan nira ke dalam media pemeliharaan larva dengan konsentrasi 2,4 ml/l, konsentrasi 4,8 ml/1, konsentrasi 7,2 ml/l dan tanpa penambahan nira (0 $\mathrm{ml} / \mathrm{l}$ ) sebagai kontrol. Penelitian ini dilaksanakan di Balai Budidaya Laut Sekotong, Kabupaten Lombok Barat, Provinsi Nusa Tenggara Barat selama 30 hari mulai dari tanggal 31 Agustus 2019 - 24 September 2019. Hasil penelitian menunjukkan bahwa penambahan nira ke dalam media pemeliharaan larva ikan bandeng memberikan pengaruh yang nyata pada sintasan dan pertumbuhan larva ikan bandeng $\left(F_{\text {hit }}>F_{\text {tab } 5 \%}\right)$. Sintasan larva, laju pertumbuhan spesifik harian bobot tubuh dan pertumbuhan mutlak panjang total larva tertinggi diperoleh pada perlakuan konsentrasi nira 7,2 ml/l dengan nilai masing-masing parameter yaitu 67,85\%, 15,25\% per hari dan 9,05 mm selama 18 hari pemeliharaan. Ketiga parameter pada perlakuan konsentrasi ini tidak menunjukkan perbedaan yang nyata dengan perlakuan konsentrasi nira 4,8 ml/1 dan 2,4 $\mathrm{ml} / \mathrm{l}$ namun berbeda nyata dengan perlakuan kontrol $(0 \mathrm{ml} / \mathrm{l})$. Disarankan untuk menerapkan penambahan nira dalam media pemeliharaan larva ikan bandeng dengan konsentrasi maksimum $7,2 \mathrm{ml} / \mathrm{l}$. Perlu dilakukan penelitian lebih lanjut tentang peningkatan konsentrasi nira di atas 7,2 $\mathrm{ml} / \mathrm{l}$ pada media pemeliharaan larva ikan bandeng untuk mendapatkan konsentrasi yang optimum bagi sintasan dan pertumbuhan larva ikan bandeng.
\end{abstract}

Kata Kunci: Larva bandeng, nira, pertumbuhan, sintasan

\begin{abstract}
The aims of the study were to determine the effect of sap concentration of areng palm (Arenga pinnata) on the survival and growth of milkfish larvae (Chanos chanos Forskal) and to get the best sap concentration for the survival and growth of milkfish larvae. The study used an experimental method and the experimental units randomized using a Completely Randomized Design (CRD) consisting of four treatments and each treatment was repeated three times. The treatments tested were the addition of areng palm sap into larval rearing media with a concentration of $2.4 \mathrm{ml} / \mathrm{l}, 4.8 \mathrm{ml} / \mathrm{l}$ and $7.2 \mathrm{ml} / \mathrm{l}$. The treatment without adding areng palm sap was used as a control. This research was conducted at the Marine Aquaculture Development
\end{abstract}


Center, Sekotong, West Lombok Regency, West Nusa Tenggara Province for 30 days starting from 31 August 2019 - 24 September 2019. The results showed that the addition of areng palm sap into the milkfish larvae rearing media had a significant effect in the survival and growth of milkfish larvae $(F$-value $>F$ crit 5\%). Larval survival, daily specific growth rate of body weight and absolute growth of the larval total length were obtained in the treatment of $7.2 \mathrm{ml} / \mathrm{l}$ with the value of each parameter is $67.85 \%, 15.25 \%$ per day and $9.05 \mathrm{~mm}$ for 18 days of maintenance. The three parameters in this concentration treatment did not show any significant difference with the treatment of $4.8 \mathrm{ml} / \mathrm{l}$ and $2.4 \mathrm{ml} / \mathrm{l}$ of areng palm sap concentration but were significantly different to the control treatment $(0 \mathrm{ml} / \mathrm{l})$. It is recommended to apply the addition of areng palm sap in the maintenance media of milkfish larvae with a maximum concentration of $7.2 \mathrm{ml} / \mathrm{l}$. Further research needs to be done about increasing the concentration of areng palm sap above $7.2 \mathrm{ml} / \mathrm{l}$ in the media of milkfish larvae maintenance to get the optimum concentration for the survival and growth of milkfish larvae.

Keywords: Milkfish larvae, areng palm sap, growth, survival rate

\section{PENDAHULUAN}

Bandeng (Chanos chanos Forskal) merupakan salah satu ikan yang memiliki nilai ekonomi tinggi yang banyak dibudidaya di tambak-tambak air payau di Indonesia. Menurut Romadon dan Subekti (2011), harga bibit ikan bandeng (nener) per seribu ekor ukuran 2,0-2,5 cm sekitar 75.000 rupiah sedangkan ukuran $5-7 \mathrm{~cm}$ sekitar 150.000 rupiah. Ikan bandeng menempati posisi yang sangat penting dalam pemenuhan kebutuhan protein masyarakat karena harganya relatif murah. Permintaan ikan bandeng (Chanos chanos Forskal) setiap tahun cukup besar baik untuk konsumsi lokal, ikan umpan bagi industri perikanan tuna, maupun untuk pasar ekspor. Berdasarkan data BPS tahun 2014 dalam Ananta (2017) bahwa tingkat konsumsi bandeng nasional rata-rata sebesar 1,40 kg/kapita dimana serapan pasar di tingkat rumah tangga sebesar 352.718 ton. Oleh karena itu, ketersediaan benih yang berkualitas dan berkesinambungan sangat diperlukan oleh industri budidaya ikan bandeng.

Menurut SNI (2013) data sintasan nener ikan bandeng selama ini masih berkisar $30 \%$ dengan pertumbuhan berkisar 14 - $17 \mathrm{~mm}$ dalam 30 hari masa pemeliharaan. Untuk meningkatkan sintasan dan pertumbuhan larva ikan bandeng maka diperlukan suatu rekayasa budidaya agar diperoleh produksi yang optimal. Penambahan sumber karbon organik pada pemeliharaan larva ikan bandeng merupakan salah satu cara yang dilakukan untuk meningkatkan kelangsungan hidup dan pertumbuhan larva ikan bandeng. Penambahan sumber karbon organik dalam media air akan dapat meningkatkan rasion $\mathrm{C} / \mathrm{N}$ sehingga dapat mempercepat pertumbuhan bakteri heterotrof yang berperan dalam merubah limbah anorganik dan organik menjadi protein mikrobial yang dapat dikonsumsi oleh larva ikan sekaligus dapat meningkatkan dan menjaga kualitas air dalam kondisi optimal. Selama ini, sumber $\mathrm{C}$ (karbon) organik yang digunakan adalah tetes tebu (molase). Penambahan sumber $\mathrm{C}$ dari tetes tebu telah berhasil meningkatkan sintasan dan pertumbuhan benih ikan bandeng (Supriyatna et al., 2013; Aslianti et al., 2014). Namun demikian tanaman ini tidak ditemukan dalam skala besar di setiap daerah seperti di pulau Lombok sehingga pengadaan bahan baku ini akan sulit dipenuhi. Sebagai alternatif sumber karbon lain pengganti tetes tebu yaitu nira dari pohon palemyang jumlahnya cukup banyak di NTB. Gede dan Purwata (2019) melaporkan bahwa Desa Kekait, Kecamatan Gunung Sari, Kabupaten lombok Lombok Barat memiliki kebun tanaman nira seluas 80 ha dengan produksi mencapai 1.000 liter per hari. Penelitian ini bertujuan untuk mengetahui pengaruh 
konsentrasi tetes nira aren terhadap sintasan dan pertumbuhan larva ikan bandeng (Chanos chanos Forskal).

\section{METODE PENELITIAN Waktu dan Tempat}

Penelitian ini dilaksanakan di Balai Budidaya Laut (BBL) Sekotong, Dusun Gili genting-Sekotong Barat, Kecamatan Sekotong, Kabupaten Lombok Barat, Nusa Tenggara Barat selama 30 hari mulai dari tanggal 31 Agustus 2019 - 24 September 2019.

\section{Rancangan Percobaan}

Penelitian ini menggunakan metode eksperimen dengan melakukan serangkaian percobaan penambahan tetes nira dari tandan bunga pohon aren (Arenga pinnata) (Gambar 1.) yang baru mekar ke dalam media pemeliharaan ikan bandeng sebanyak yaitu 2,4 ml/l (perlakuan A), 4,8 $\mathrm{ml} / \mathrm{l}$ (perlakuan B), 7,2 ml/1 (perlakuan C) dan tanpa penambahan tetes nira (kontrol perlakuan, K). Penelitian ini menggunakan Rancangan Acak Lengkap (RAL). Masingmasing perlakuan diulang sebanyak 3 kali ulangan.

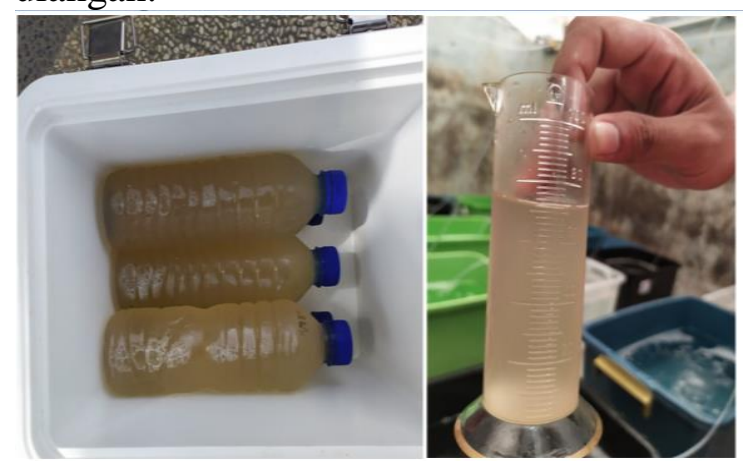

Gambar 1. Tetes nira dari tandan bunga pohon aren (Arenga pinnata) dalam coller boks (kiri) dan sampel nira yang dimasukkan ke dalam wadah percobaan (kanan).

\section{Prosedur Penelitian Persiapan}

Tetes nira dikoleksi dari pedagang tuak manis (tetes nira) di Desa Kekait, Kecamatan Gunung Sari, Lombok Barat.
Sebanyak lima liter nira segar dari tandan bunga pohon aren yang baru mekar ditransportasi ke lokasi penelitian menggunakan cooler box yang diisi es batu. Sebelum digunakan, tetes nila disaring menggunakan jaring plankton 150 mikron. Tetes nira kemudian dimasukkan ke dalam wadah pemeliharaan larva ikan bandeng yaitu 12 kontainer yang masing-masing berukuran $54 \mathrm{~cm} \mathrm{x} 36 \mathrm{~cm} \mathrm{x} 28 \mathrm{~cm}$ berisi air laut bersalinitas $30 \mathrm{ppt}$ sebanyak 301 (Gambar 2A). Sebelum digunakan, air laut telah didisinfeksi dengan kaporit 15 ppm dan di-deklorinasi menggunakan natrium tiosulfat $5 \mathrm{ppm}$. Jumlah tetes nira yang dimasukan disesuaikan dengan konsentrasi perlakuan. Probiotik EM4 (Gambar 2B) perikanan juga ditambahkan sebanyak 0,01 $\mathrm{ml} / \mathrm{l}$ sebagai starter dan dibiarkan di dalam media selama 7 hari.

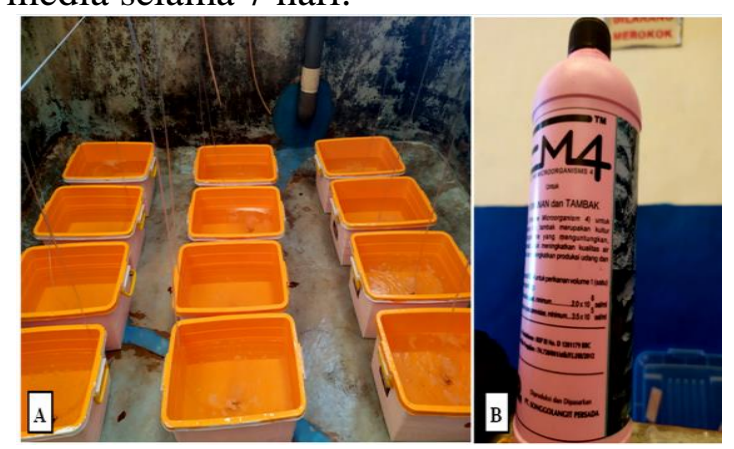

Gambar 2. Wadah kontainer berukuran 54 $\mathrm{cm} \times 36 \mathrm{~cm} \times 28 \mathrm{~cm}$ yang digunakan sebagai wadah percobaan (A), dan Probiotik EM4 yang digunakan sebagai starter (B).

Telur ikan bandeng didatangkan dari unit usaha pembenihan ikan bandeng yang ada di Desa Musi, Kecamatan Gerokgak, Kabupaten Buleleng, Bali. Sebanyak 50.000 butir telur ikan bandeng dimasukkan ke dalam cooler box dan ditransportasikan melalui darat menggunakan kendaraan bermotor. Telur ikan bandeng disaring pada serok lembut dan dipindahkan ke dalam dua bak penetasan yaitu bak akuarium masingmasing berkapasitas 80 liter yang diisi air laut sebanyak 60 liter per akuarium. Telur ditebar dengan dengan kepadatan 25.000 
butir per akuarium. Wadah penetasan diberi aerasi secara terus menerus hingga telur menetas. Larva yang baru menetas (sekitar 24 jam setelah fertilisasi) disaring pada serok lembut dan dipindahkan ke wadah akuarium baru dengan kapasitas dan volume air yang sama dengan bak penetasan. Wadah penampungan larva diberi aerasi secara terus menerus hingga larva mencapai umur 2 hari untuk dilakukan penebaran pada unit percobaan. Larva disaring pada serok lembut kemudian dimasukkan ke dalam wadah plastik yang diisi air laut sebanyak 25 liter untuk dilakukan sampling kepadatan menggunakan wadah beaker glass kapasitas $150 \mathrm{ml}$. Sebelum dilepas ke dalam wadah percobaan, larva ikan bandeng diaklimatisasi terlebih dahulu pada wadah percobaan selama 15 menit kemudian dilepas ke dalam wadah percobaan dengan kepadatan 15 ekor per liter

Penambahan tetes nira dilakukan berulang setiap 7 hari dimulai pada awal percobaan (saat larva berumur 2 hari), hari ke 7 dan hari ke 14 masa pemeliharaan. Pakan utama yaitu Brachionus sp. diberikan sejak awal percobaan dengan kepadatan 5 ind $/ \mathrm{ml}$ dan terus ditingkatkan hingga 30 ind/ml hingga 18 hari masa pemeliharaan. Penambahan fitoplankton berupa Nanchloropsis spp. juga dilakukan setiap hari sekali sebanyak 5-7 \% dari volume media pemeliharaan.

\section{Pemeliharaan Ikan Uji}

Pengukuran panjang dan bobot tubuh dilakukan pada awal pemeliharaan $(t=0$ hari) dan akhir pemeliharaan $(t=18$ hari). Sampling awal dilakukan dengan mengamati 40 ekor larva $(n=40$ ekor) sedangkan sampling akhir dilakukan dengan mengamati 10 ekor benih dari masing-masing wadah percobaan $(n=10$ ekor). Pengukuran panjang larva menggunakan mikrometer digital ketelitian $0,01 \mathrm{~mm}$ sedangkan penimbangan bobot tubuh dilakukan dengan menggunakan timbangan analitik ketelitian 0,0001 g. Pada akhir percobaan juga dilakukan penghitungan jumlaha larva yang hidup.

\section{Parameter Kualitas Air}

Parameter kualitas air yang diamati dalam penelitian ini meliputi suhu, salinitas, derajat keasaman $(\mathrm{pH})$, oksigen terlarut (DO), amonia, dan total bakteri. Pengukuran suhu, salinitas, dan $\mathrm{pH}$ dilakukan setiap hari sekali sedangkan amonia, DO dan jumlah total bakteri dilakukan setiap 7 hari sekali. Pengukuran $\mathrm{pH}$ dan suhu dilakukan dengan menggunakan alat tri meter pada kedalaman air sekitar $5 \mathrm{~cm}$. Pengukuran salinitas dilakukan menggunakan alat refraktometer sedangkan DO diukur dengan menggunakan DO meter. Pengukuran amonia dilakukan menggunakan alat spektrofotometer. Pengukuran total bakteri dilakukan dengan menggunakan metode total plate count.

\section{Parameter Uji}

Kelangsungan Hidup (SR)

Sintasan larva ikan bandeng ditentukan dengan menggunakan rumus yaitu :

$$
\mathrm{SR}=N_{t} / N_{0} \times 100 \% .
$$

Keterangan :

$\mathrm{SR}=$ sintasan atau survival rate $(\%)$;

$N t=$ Jumlah ikan yang hidup pada akhir percobaan;

$N_{0}=$ Jumlah ikan yang hidup pada awal percobaan.

\section{Laju pertumbuhan spesifik (LPS)}

Laju pertumbuhan spesifik (LPS) harian bobot tubuh ditentukan dengan menggunakan rumus menurut Mukhlis et al. (2017) yaitu :

$$
\mu=\left(\left(\sqrt[t]{W_{t} / W_{0}}\right)-1\right) \times 100 \% \text {. }
$$

Keterangan :

$\mu=$ Laju pertumbuhan spesifik harian (\%/hari); 
$W t=$ Bobot rata-rata pada akhir percobaan (mg);

$W_{0}=$ Bobot rata-rata pada awal percobaan (mg);

$t=$ Lama masa percobaan (hari).

\section{Pertumbuhan Mutlak}

Pertumbuhan mutlak panjang total larva ikan bandeng ditentukan dengan menggunakan rumus menurut Effendie (1997) yaitu :

$$
\Delta L=L_{t}-L_{0}
$$

Keterangan :

$\Delta L=$ pertumbuhan mutlak $(\mathrm{cm})$;

$L_{t}=$ Panjang awal $(\mathrm{cm}) ; L_{0}=$ panjang akhir (cm).

\section{Analisis Data}

Parameter uji dianalisis secara statistik menggunakan analisis sidik ragam pada taraf ntara 5\%. Jika hasil uji statistik menunjukkan adanya pengaruh nyata ( $F$ hit $>F 5 \%$ ), maka analisis data dilanjutkan dengan uji beda rerata antar perlakuan menggunakan uji BNJ dan BNT.

\section{HASIL}

\section{Sintasan larva}

Sintasan larva atau survival rate (SR) ikan bandeng yang diamati pada akhir percobaan memperlihatkan adanya perbedaan antar perlakuan. Hasil pengamatan menunjukkan bahwa semakin tinggi konsentrasi nira maka sintasan larva ikan bandeng semakin tinggi mengikuti persamaan kuadratik $y=0,794 x^{2}-0,327 x+$ 29,07 dengan nilai koefisien determinasi $R^{2}$
$=0,941$ (Gambar 3). Pada kisaran konsentrasi nira yang diuji yaitu $0-7,2$ $\mathrm{ml} / \mathrm{l}$, nilai sintasan larva ikan bandeng tertinggi diperlihatkan oleh perlakuan konsentrasi $7,2 \mathrm{ml} / \mathrm{l}$ dengan nilai rata-rata sebesar $67,85 \%$ selanjutnya diikuti oleh perlakuan konsentrasi $4,8 \mathrm{ml} / \mathrm{l}$ sebesar $45,93 \%$, kemudian perlakuan konsentrasi 2,4 $\mathrm{ml} / \mathrm{l}$ sebesar $32,74 \%$ dan perlakuan kontrol (tanpa penambahan nira) yaitu sebesar 29,11\%. Hasil analisis keragaman menunjukkan bahwa nilai $F_{\text {hit }}>F_{\text {tab }} 5 \%$ artinya bahwa perbedaan konsentrasi nira pada media pemeliharaan larva ikan bandeng memberi pengaruh yang nyata (signifikan) pada sintasan larva ikan bandeng (Chanos chanos Forskal). Hasil uji lanjut menggunakan uji Beda Nyata Terkecil (BNT) memperlihatkan bahwa sintasan tertinggi yang diperoleh dalam perlakuan ini (konsentrasi 7,2 ml/l) berbeda nyata dengan tiga perlakuan lainnya (Tabel $1)$.

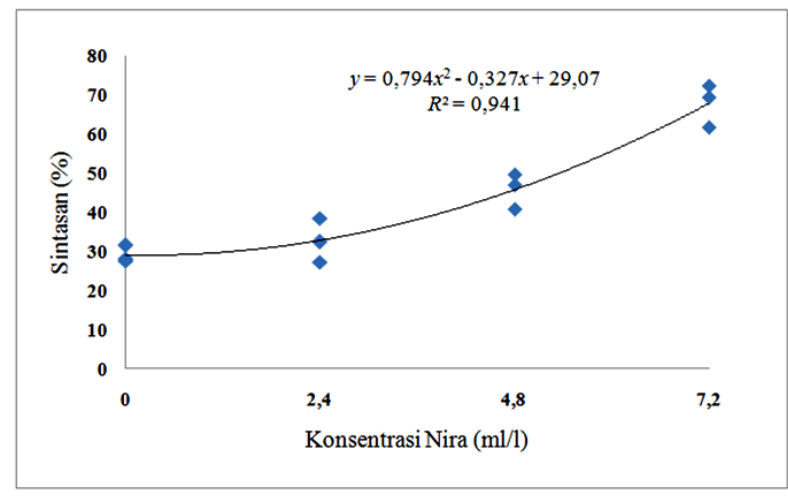

Gambar 3. Grafik pola hubungan antara sintasan larva ikan bandeng dengan konsentrasi nira.

Tabel 1. Nilai sintasan larva ikan bandeng pada media dengan kandungan nira konsentrasi 0 $\mathrm{ml} / \mathrm{l}, 2,4 \mathrm{ml} / \mathrm{l}, 4,8 \mathrm{ml} / \mathrm{l}$ dan $7,2 \mathrm{ml} / \mathrm{l}$

\begin{tabular}{|c|c|c|c|c|}
\hline \multirow{2}{*}{ Konsentrasi Nira $(\mathrm{ml} / \mathrm{l})$} & \multicolumn{3}{|c|}{ Nilai Sintasan $(\mathrm{ml} / \mathrm{l})$ pada Ulangan } & \multirow{2}{*}{$\begin{array}{l}\text { Rata-rata }(\mathrm{ml} / \mathrm{l}) \text { dan } \\
\text { notasi signifikansi }\end{array}$} \\
\hline & I & II & III & \\
\hline 0 & 31,6 & 28,2 & 27,6 & $29,1^{\mathrm{a}}$ \\
\hline 2,4 & 38,4 & 27,3 & 32,4 & $32,7^{\mathrm{b}}$ \\
\hline 4,8 & 47,1 & 40,9 & 49,8 & $45,9^{\mathrm{c}}$ \\
\hline 7,2 & 61,8 & 69,3 & 72,4 & $67,9^{\mathrm{d}}$ \\
\hline
\end{tabular}

BNT 0,05 = 3,80 
Jurnal Perikanan (2020) Volume 10. No. $1: 29-40$

DOI : https://doi.org/10.29303/jp.v10i1.177

\section{Laju Pertumbuhan Spesifik Harian Bobot Tubuh}

Hasil analisis data laju pertumbuhan spesifik (LPS) harian bobot tubuh larva ikan bandeng yang dipelihara selama 18 hari menunjukkan bahwa perlakuan konsentrasi nira 7,2 ml/l menghasilkan LPS harian tertinggi dengan nilai rata-rata sebesar $15,25 \%$, selanjutnya diikuti oleh perlakuan nira $4,8 \mathrm{ml} / \mathrm{l}$ dengan nilai ratarata sebesar $14,61 \%$, perlakuan konsentrasi nira 2,4 ml/l dengan nilai rata-rata sebesar $14,41 \%$ dan yang terendah pada perlakuan kontrol (konsentrasi nira $0 \%$ ) dengan nilai rata-rata sebesar $13,29 \%$. Data ini menunjukkan bahwa pada kisaran konsentrasi nira $0-7,2 \mathrm{ml} / \mathrm{l}$, semakin tinggi konsentrasi nira maka LPS harian larva ikan bandeng semakin tinggi mengikuti persamaan kuadratik $y=-0,021 x^{2}+0,404 x$ $+13,35$ dengan nilai koefisien determinasi $R^{2}=0,615$ (Gambar 4). Hasil analisis keragaman menunjukkan bahwa nilai $F_{\text {hit }}>$ $F_{\text {tab 5\% }}$ artinya bahwa perbedaan konsentrasi nira pada media pemeliharaan larva ikan bandeng memberi pengaruh yang nyata (signifikan) pada LPS harian bobot tubuh larva ikan bandeng (Chanos chanos Forskal). Hasil uji lanjut menggunakan uji Beda Nyata Jujur (BNJ) memperlihatkan bahwa LPS harian bobot tubuh tertinggi yang diperoleh pada perlakuan konsentrasi nira $7,2 \mathrm{ml} / \mathrm{l}$ terlihat tidak berbeda nyata dengan LPS harian perlakuan konsentrasi nira $4,8 \mathrm{ml} / \mathrm{l}$ dan $2,4 \mathrm{ml} / \mathrm{l}$, namun berbeda nyata dengan perlakuan kontrol (Tabel 2).

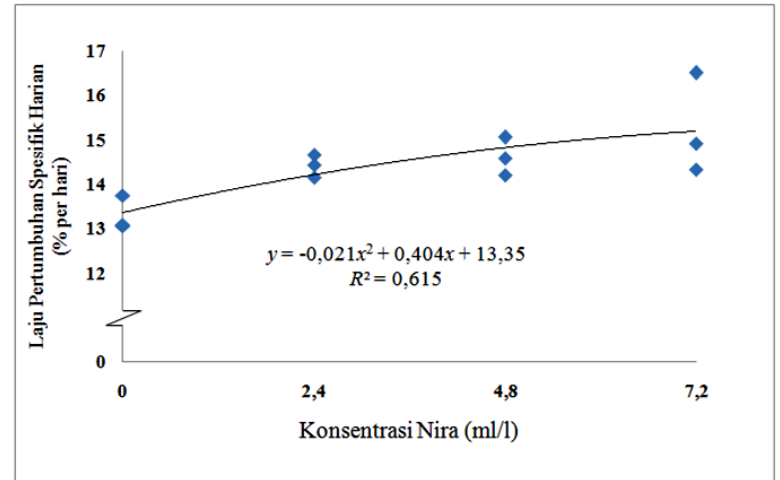

Gambar 4. Grafik pola laju pertumbuhan spesifik harian bobot tubuh larva ikan bandeng pada media dengan penambahan nira konsentrasi $0 \mathrm{ml} / \mathrm{l}, 2,4 \mathrm{ml} / \mathrm{l}, 4,8$ $\mathrm{ml} / \mathrm{l}$, dan $7,2 \mathrm{ml} / \mathrm{l}$.

Tabel 2. Nilai bobot tubuh larva ikan bandeng pada $t=0, t=18$ dan laju pertumbuhan spesifik harian bobot tubuh larva ikan bandeng pada media dengan kandungan nira konsentrasi $0 \mathrm{ml} / \mathrm{l}, 2,4 \mathrm{ml} / \mathrm{l}, 4,8 \mathrm{ml} / 1$ dan 7,2 $\mathrm{ml} / 1$ serta notasi signifikansi hasil uji lanjut Beda Nyata Jujur.

\begin{tabular}{llllll}
\hline $\begin{array}{l}\text { Konsentrasi } \\
\text { Nira }(\mathrm{ml} / \mathrm{l})\end{array}$ & Ulangan & $W_{0}(\mathrm{mg})$ & $W_{18}(\mathrm{mg})$ & $\begin{array}{l}\text { LPS harian } \\
(\% \text { per hari) }\end{array}$ & $\begin{array}{l}\text { Rata-rata }(\% \text { per hari) } \\
\text { dan } \\
\text { notasi signifikansi }\end{array}$ \\
\hline \multirow{3}{*}{ Kontrol } & I & 0.49 & 4.46 & 13.05 & \\
& II & 0.49 & 4.97 & 13.74 & $13.29^{\mathrm{a}}$ \\
& III & 0.49 & 4.48 & 13.08 & \\
2.4 & I & 0.49 & 5.75 & 14.66 & \\
& II & 0.49 & 5.31 & 14.15 & $14.41^{\mathrm{ab}}$ \\
& III & 0.49 & 5.54 & 14.42 & \\
\hline \multirow{3}{*}{4.8} & I & 0.49 & 5.68 & 14.58 & \\
& II & 0.49 & 5.36 & 14.21 & $14.61^{\mathrm{ab}}$ \\
& III & 0.49 & 6.11 & 15.05 & \\
& I & 0.49 & 5.46 & 14.33 & \\
& II & 0.49 & 5.99 & 14.92 & $15.25^{\mathrm{b}}$ \\
\hline
\end{tabular}

BNJ 0,05 = 1,679 


\section{Pertumbuhan mutlak panjang total tubuh}

Hasil pengukuran pertumbuhan mutlak panjang total larva larva ikan bandeng yang dipelihara selama 18 hari menunjukkan bahwa pertumbuhan tertinggi diperlihatkan oleh larva pada perlakuan konsentrasi nira 7,2 $\mathrm{ml} / \mathrm{l}$ dengan pertambahan panjang tubuh sebesar 9,05 $\mathrm{mm}$, kemudian diikuti oleh perlakuan konsentrasi nira 4,8 ml/1 sebesar $8,82 \mathrm{~mm}$, selanjutnya perlakuan konsentrasi nira 2,4 $\mathrm{ml} / \mathrm{l}$ sebesar $8,47 \mathrm{~mm}$ dan terendah pada perlakuan konsentasi nira $0 \%$ (kontrol) yaitu sebesar 6,42 mm. Pola pertumbuhan mutlak panjang total larva ikan bandeng mengikuti persamaan kuadratik yaitu : $y=$ $0,079 x^{2}+0,9,14 x+6,496$ dengan nilai koefisien determinasi $R^{2}=0,843$ (Gambar $5)$.

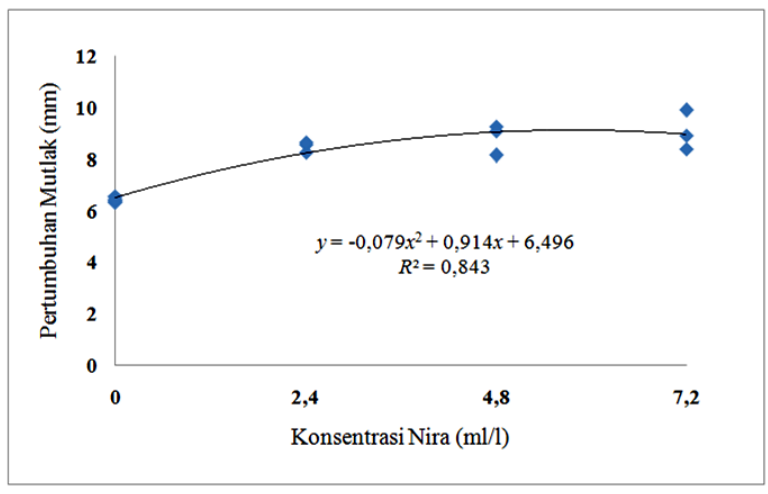

Gambar 5. Grafik pola hubungan antara pertumbuhan mutlak panjang total larva ikan bandeng pada perlakuan konsentrasi nila 0 $\mathrm{ml} / \mathrm{l}, 2,4 \mathrm{ml} / \mathrm{l}, 4,8 \mathrm{ml} / \mathrm{l}$, dan 7,2 $\mathrm{ml} / \mathrm{l}$.

Hasil analisis keragaman menunjukkan bahwa nila $F_{\text {hit }}>F$ tab $5 \%$ artinya bahwa perbedaan konsentrasi nila pada media pemeliharaan larva ikan bandeng memberi pengaruh yang nyata (signifikan) pada pertumbuhan mutlak panjang total larva ikan bandeng (Chanos chanos Forskal). Berdasarkan hasil uji lanjut menggunakan uji BNJ diperoleh bahwa respon pertumbuhan mutlak tertinggi yang diperlihatkan oleh perlakuan konsentrasi 7,2 $\mathrm{ml} / \mathrm{l}$ berbeda nyata dengan perlakuan kontrol (tanpa penambahan nira) namun tidak berbeda nyata dengan konsentrasi nira $4,8 \mathrm{ml} / \mathrm{l}$ dan 2,4 ml/l (Tabel $3)$.

Tabel 3. Tabel panjang total larva ikan bandeng (Chanos chanos Forskal) pada saat $t=0$ hari, $t=18$ hari, pertumbuhan mutlak panjang total larva dan rata-rara pertumbuhan mutlak panjang larva pada perlakuan konsentrasi nira $0 \mathrm{ml} / \mathrm{l}, 2,4 \mathrm{ml} / \mathrm{l}, 4,8 \mathrm{ml} / \mathrm{l}$ dan $7,2 \mathrm{ml} / \mathrm{l}$, serta notasi signifikansi hasil uji lanjut BNJ 5\%.

\begin{tabular}{llllll}
\hline $\begin{array}{l}\text { Konsentrasi } \\
\text { Nira }(\mathrm{ml} / \mathrm{l})\end{array}$ & Ulangan & $L_{0}(\mathrm{~mm})$ & $L_{18}(\mathrm{~mm})$ & $\begin{array}{l}\text { Pertumbuhan } \\
\text { Mutlak } \\
(\mathrm{mm})\end{array}$ & $\begin{array}{l}\text { Rata-rata }(\mathrm{mm}) \text { dan } \\
\text { notasi signifikansi }\end{array}$ \\
\hline \multirow{2}{*}{ Kontrol (0) } & I & 4.57 & 11.10 & 6.53 & \multirow{2}{*}{$6.42^{\mathrm{a}}$} \\
& II & 4.57 & 10.88 & 6.31 & \\
& III & 4.57 & 10.98 & 6.41 & \multirow{2}{*}{$8.47^{\mathrm{b}}$} \\
\multirow{2}{*}{2.4} & I & 4.57 & 13.11 & 8.54 & \\
& II & 4.57 & 12.83 & 8.26 & $8.82^{\mathrm{b}}$ \\
\hline \multirow{2}{*}{4.8} & III & 4.57 & 13.19 & 8.62 & \\
\hline
\end{tabular}


Jurnal Perikanan (2020) Volume 10. No. $1: 29-40$

DOI : https://doi.org/10.29303/jp.v10i1.177

\begin{tabular}{llllll}
\hline & III & 4.57 & 12.71 & 8.14 & \\
\hline \multirow{3}{*}{7.2} & I & 4.57 & 12.95 & 8.38 & \\
& II & 4.57 & 13.46 & 8.89 & $9.05^{\mathrm{b}}$ \\
& III & 4.57 & 14.45 & 9.88 & \\
\hline
\end{tabular}

BNJ 0,05 = 1,298

\section{Kualitas Air}

Hasil pengamatan kualitas air meliputi suhu, salinitas, DO, $\mathrm{pH}$ dan amonia masing-masing berada pada kisaran yaitu $26,1-28,9^{\circ} \mathrm{C}, 30-35 \mathrm{ppt}, 2,7-4,9 \mathrm{ppm}$, 6,85-7,93 dan < 0,01-0,92 ppm (Tabel 4).

Tabel 4. Data kisaran kualitas air meliputi suhu, salinitas, DO, pH dan amonia selama 18 hari masa pemeliharaan larva.

\begin{tabular}{llllll}
\hline \multirow{2}{*}{$\begin{array}{l}\text { Parameter Kualitas } \\
\text { Air }\end{array}$} & \multicolumn{2}{l}{ Perlakuan Konsentrasi Nira (ml/l) } & & \multicolumn{2}{l}{$\begin{array}{l}\text { Kisaran } \\
\text { Parameter }\end{array}$} \\
\cline { 2 - 5 } & 0 & 2,4 & 4,6 & 7,2 & $26,1-28,9$ \\
\hline Suhu $\left({ }^{\circ} \mathrm{C}\right)$ & $26,2-28,1$ & $26,3-28,9$ & $26,2-28,6$ & $26,1-28,2$ & $29-35$ \\
Salinitas (ppt) & $31-35$ & $29-35$ & $30-35$ & $31-35$ & $2,7-4,9$ \\
DO (ppm) & $4,5-4,9$ & $2,8-4,7$ & $2,8-4,6$ & $2,7-4,3$ & $6,85-7,93$ \\
pH & $7,60-7,93$ & $7,20-7,81$ & $7,06-7,78$ & $6,85-7,72$ & $<0,01-0,92$ \\
Amonia (mg/l) & $<0,01-0,92$ & $<0,01-0,05$ & $<0,01-0,03$ & $<0,01-0,02$ & \\
\hline
\end{tabular}

\section{Total Bakteri}

Hasil pengamatan total bakteri dari sampel media air menunjukkan adanya perbedaan jumlah bakteri antara perlakuan kontrol dengan perlakuan penambahan nira di semua konsentrasi. Hasil pengukuran menunjukkan bahwa total bakteri tertinggi terdapat pada perlakuan konsentrasi nira 7,2 $\mathrm{ml} / \mathrm{l}$ dengan kisaran yaitu 4,6 x $10^{6} \mathrm{CFU} / \mathrm{ml}$ - $1,2 \times 10^{9} \mathrm{CFU} / \mathrm{ml}$, kemudian perlakuan konsentrasi nira 4,8 ml/l dengan kisaran antara $2,2 \times 10^{6} \mathrm{CFU} / \mathrm{ml}-9,3 \times 10^{8}$ $\mathrm{CFU} / \mathrm{ml}$, selanjutnya perlakuan konsentrasi nira $2,4 \mathrm{ml} / \mathrm{l}$ ) dengan kisaran antara $1,4 \mathrm{x}$ $10^{5} \mathrm{CFU} / \mathrm{ml}-1,1 \times 10^{8} \mathrm{CFU} / \mathrm{ml}$. Total bakteri terendah terdapat pada perlakuan kontrol dengan nilai berkisar 3,7 x $10^{5}$ $\mathrm{CFU} / \mathrm{ml}-2,9 \times 10^{4} \mathrm{CFU} / \mathrm{ml}$. Data ini menunjukkan bahwa penambahan sumber karbon di dalam media percobaan telah dimanfaatkan oleh bakteri heterotrof untuk pertumbuhan koloninya yang terlihat dari peningkatan total bakteri pada media yang dtambahkan nira dibandingkan dengan media kontrol tanpa penambahan nira.

\section{Warna Air}

Penambahan sumber carbon organik pada media pemeliharaan telah mempengaruhi perubahan warna air. Pada perlakuan kontrol, warna terlihat bening mulai dari awal hingga khir percobaan. Pada perlakuan penambahan nira, semakin tinggi konsentrasi nira maka warna air semakin keruh dan cenderung mengarak ke kecoklatan. Media air pada perlakuan konsentrasi nira 2,4 ml/l terlihat berwarna putih bening mulai dari awal hingga akhir pemeliharaan. Selanjutnya pada perlakuan konsentrasi nira 4,8 $\mathrm{ml}$ terlihat warna putih keruh mulai dari awal hingga akhir pemeliharaan, dan pada perlakuan konsentrasi nira 7,2 ml/1 media air terlihat berwarna warna putih kecoklatan mulai dari awal hingga akhir masa pemeliharaan.

\section{PEMBAHASAN}

Nilai kisaran parameter kualitas air selama percobaan masih berada dalam kisaran layak pertumbuhan hewan uji dan juga mikroba yang menguntungkan dalam media percobaan. Penambahan nira sebagai sumber karbon terbukti telah meningkatkan jumlah koloni bakteri heterotrof sebagai bioflok yang dapat dikonsumsi oleh larva ikan bandeng sebagai sumber protein 
alternatif selain Brachiouns sp. dan Nannochloropsis spp. Menurut Zulfahmi et al. (2018), pemeliharaan dengan penambahan bioflok memberikan nilai lebih dibandingkan pemeliharaan tanpa bioflok, dengan kualitas air yang terkontrol sehingga tidak perlu melakukan pergantian air. Meskipun selama percobaan 18 hari tidak dilakukan pergantian air, namun sintasan, laju pertumbuhan spesifik harian bobot tubuh, pertumbuhan mutlak panjang total tubuh larva ikan bandeng pada perlakuan penambahan nira dengan konsentrasi 7,2 $\mathrm{ml} / \mathrm{l}$ terlihat jauh lebih tinggi dan berbeda nyata dengan perlakuan kontrol (tanpa penambahan nira dalam media pemeliharaan). Hal ini menunjukkan bahwa penambahan nira dalam media telah meningkatkan ketersediaan pakan yang cukup dan kualitas lingkungan yang lebih baik dibandingkan dengan perlakuan kontrol.

Nilai suhu antar perlakuan relatif sama dan secara keseluruhan berkisar dari 26,1-28,9 ${ }^{\circ}$ C. Kisaran suhu selama penelitian ini tergolong dalam kategori baik. Gustiana (2018) mengatakan bahwa nilai suhu yang baik untuk kehidupan ikan di daerah tropis berkisar antara $25-32^{\circ} \mathrm{C}$. Kisaran salinitas antar perlakuan juga terlihat terlihat relatif sama dengan nilai kisaran dari 29-35 ppt. Kisaran salinitas ini termasuk dalam kisaran yang mendukung kehidupan larva ikan bandeng karena telah diketahui bahwa larva ikan bandeng memiliki ketahan terhadap kisaran salinitas yang luas (euryhaline). Kandungan oksigen terlarut (DO) pada perlakuan kontrol terlihat cenderung lebih tinggi dibandingkan dengan dengan perlakuan penambahan nira (Tabel 4). Rendahnya kandungan oksigen pada perlakuan penambahan nira diduga karena tingginya persaingan oksigen antara organisme yang hidup dalam media percobaan. Data total bakteri menunjukkan bahwa jumlah koloni bakteri dalam media dengan penambahan nira cenderung lebih tinggi dibandingkan dengan perlakuan kontrol. Meskipun penambahan nira memperlihatkan kandungan oksigen yang relatif rendah, namun nilai sintasan, laju pertumbuhan spesifik harian bobot tubuh, serta pertumbuhan mutlak panjang total larva cenderung lebih tinggi dibandingkan dengan perlakuan kontrol. Hal ini menunjukkan perlunya peningkatan oksigenasi dalam media yang diberi tambahan nira dalam media pemeliharaan. Menurut Mas'ud (2011) bahwa oksigen terlarut yang baik dalam pemeliharaan ikan berkisar antara 3-5 ppm. Derajat keasaman air yang diukur selama percobaan menunjukkan nilai yang relatif sama antar perlakuan dan nilai yang diamati berada pada kisaran yang layak bagi kehidupan larva ikan bandeng. Gustiana (2018) mengatakan bahwa nilai $\mathrm{pH}$ yang dapat ditolerir oleh ikan berkisar antara 7-8,5. Amonia merupakan hasil sisa metabolisme dan sisa pakan yang tidak termakan oleh ikan. Hasil pengukuran konsentrasi amonia pada penelitian ini menunjukkan bahwa kandungan amonia pada media perlakuan dengan penambahan nira cenderung lebih randah dibandingkan dengan perlakuan kontrol (Tabel 4). Rendahnya kandungan amonia diduga karena adanya proses perombakan amonia oleh bakteri/mikroorganisme menjadi biomassa mikroba (bahan organik) yang bermanfaat bagi kehidupan larva yang mendukung pertumbuhan dan kelangsungan hidupnya. Suwoyo et al. (2012) menjelaskan bahwa batas maksimum konsentrasi amonia di perairan yaitu $1,5 \mathrm{ppm}$.

Pentingnya penambahan sumber karbon organik di dalam media air dijelaskan Avnimelech (1999) bahwa karbon organik merupakan satu diantara sumber karbohidrat yang dapat dimanfaatkan untuk meningkatkan $\mathrm{C} / \mathrm{N}$ rasio dalam upaya mempercepat tumbuhnya mikroorganisme terutama bakteri heterotrof. Bakteri heterotrof akan berkembang pesat jika cukup tersedia sumber C-karbohidrat seperti sukrosa, molase dan tepung tapioka. Suwoyo et al. (2012) mengatakan bioflok merupakan komunitas mikroba yang mencapai 
kepadatan >10 $\mathrm{CFU} / \mathrm{ml}$. Peningkatan jumlah bakteri disebabkan oleh pengaruh pemberian nira yang merupakan sumber karbon organik yang dapat meningkatkan pertumbuhan bakteri heterotrof. Perubahan warna air juga dapat menjadi indikator tingkat kematangan media bioflok, selain itu dapat menjadi indikator organisme yang tumbuh pada media bioflok. Perubahan warna air selama pemeliharaan dengan penambahan nira pada media air memberikan pengaruh perubahan warna dari bening sampai putih kecoklatan.

Penambahan sumber karbon organis juga telah meningkatkan sintasan, laju pertumbuhan spesifik harian dan pertumbuhan mutlak panjang total larva ikan bandeng. Peningkatan nilai parameter pertumbuhan pada perlakuan penambahan nira diduga dipengaruhi oleh ketersediaan pakan alami yang cukup dan juga adanya pakan tambahan yang dapat dimanfaatkan oleh larva ikan bandeng.

Sintasan larva ikan bandeng pada perlakuan penambahan nira memperlihatkan peningkatan nilai yang cukup signifikan dibandingkan dengan perlakuan kontrol. Sintasan larva ikan bandeng tertinggi yang ditunjukkan oleh perlakuan konsentrasi nira $7.2 \mathrm{ml} / \mathrm{l}$ diduga dipengaruhi oleh ketersediaan pakan cukup dengan lingkungan yang baik. Pemberian nira merupakan salah satu cara yang dapat menjaga kualitas air tetap baik. Nira yang merupakan sumber karbon organik dapat meningkatkan pertumbuhan bakteri heterotrof yang berfungsi untuk mengkonversi karbon dan nitrogen dari sisa pakan dan feses menjadi biomassa bakteri, sehingga dapat menekan peningkatan jumlah amonia dalam media pemeliharaan serta biomassa bakteri yang membentuk flok dapat dimanfaatkan larva kan bandeng sebagai pakan alami tambahan. Menurut Zulfahmi et al. (2018) bahwa proses mikrobiologi yang terjadi selama pembentukan flok dapat meningkatkan kualitas air dan mengurangi beban cemaran limbah budidaya ke perairan. Sistem heterotrofik mempunyai potensi untuk diterapkan dalam pemanfaatan limbah amonia pada pemeliharaan ikan. Menurut Aslianti et al. (2014) bahwa peran kualitas air sebagai lingkungan hidup larva sangat menentukan kelangsungan hidup benih mengingat ikan bandeng termasuk jenis ikan "compensatory growth" yaitu dapat tumbuh dengan cepat jika mendapat suasana lingkungan yang baik, cocok dan banyak tersedia makanan. Perbedaan nilai sintasan yang signifikan pada setiap perlakuan diduga disebabkan oleh kualitas air lingkungan pemeliharaan larva ikan bandeng. Hal ini dapat dilihat dari nilai amonia pada perlakuan kontrol (Tabel 4). Data total jumlah bakteri pada perlakuan kontrol menujukkan nilai terendah dibandingkan tiga perlakuan lainnya. Rendahnya jumlah mikroba diduga telah berpengaruh pada rendahnya laju konversi karbon dan nitrogen menjadi flok. Pakan yang tidak termakan, feses dan produk sisa metabolisme ikan, merupakan materialmaterial buangan yang akan terakumulasi menjadi amonia dengan konsentrasi yang sangat tinggi. Ombong dan Salindeho (2016) menjelaskan bahwa materialmaterial buangan berupa sisa pakan dan feses ini akan terurai dan membentuk gasgas yang bersifat racun dan mengakibatkan beberapa parameter kualitas air akan berfluktuasi dan berada pada level yang tidak layak, khususnya, $\mathrm{DO}, \mathrm{NH}_{3}, \mathrm{NO}_{2}$, $\mathrm{NO}_{3}$. Kondisi ini pada awalnya menyebabkan organisme kultur berada dalam keadaan cekaman (stress) yang dapat mengakibatkan ketahanan dan kekebalan tubuh menurun. Ikan dalam kondisi seperti itu sangat mudah diserang oleh mikroorganisme patogenik. Jika kondisi ini dibiarkan berlarut dan tidak ditangani segera maka kematian ikan kultur akan mulai terjadi.

Sintasan berbanding lurus dengan laju pertumbuhan spesifik harian dan pertumbuhan mutlak panjang total larva ikan bandeng. Menurut De Schryver et al. (2008), pertumbuhan terjadi karena adanya suplai pakan tambahan dari flok yang ada dalam wadah pemeliharaan. Adanya 
tambahan pakan alami pada media, berasal dari asimilasi nitrogen dan carbon anorganik menjadi protein mikroba bakteri heterotrof yang telah meningkat jumlahnya dalam media pemeliharaan. Warna kecoklatan pada media bioflok menandakan bahwa media air didominasi oleh bakteri. Menurut Pramono et al. (2019) bahwa warna air selanjutnya akan berubah menjadi semakin pekat kecokelatan sejalan dengan penambahan pakan dan molase sebagai sumber karbohidrat. Warna ini menunjukkan bahwa ada perubahan dominasi dari fitoplankton ke mikroba bakteri. Suwoyo et al. (2012) juga menjelaskan bahwa sumber karbon organik berperan dalam menumbuhkan bakteri heterotrof yang dapat meningkatkan kualitas air karena adanya pemanfaatan nitrogen dalam bentuk amonia menjadi biomassa bakteri. Kondisi ini menyebabkan terjadinya keseimbangan nitrogen dan karbon dalam media budidaya. Pertumbuhan hewan uji pada perlakuan penambahan nira menunjukkan bahwa pakan yang tersedia telah mencukupi kebutuhan larva ikan dalam kondisi lingkungan yang baik.

\section{KESIMPULAN}

Penambahan nira dengan konsentrasi yang berbeda memberikan pengaruh yang nyata terhadap sintasan, laju pertumbuhan spesifik harian bobot tubuh dan pertumbuhan mutlak panjang total larva ikan bandeng. Sintasan, laju pertumbuhan spesifik harian dan pertumbuhan mutlak tertinggi terdapat pada perlakuan konsentrasi nira $7,2 \mathrm{ml} / \mathrm{l}$ dengan nilai sintasan $67,85 \%$, laju pertumbuhan spesifik harian $15,25 \%$ per hari dan pertumbuhan mutlak panjang total tubuh $9,05 \mathrm{~mm}$ selama 18 hari pemeliharaan. Sintasan, laju pertumbuhan spesifik harian dan pertumbuhan mutlak pada perlakuan konsentrasi nira 7,2 ml/l tidak berbeda nyata dengan perlakuan konsentrasi nira 4,8 $\mathrm{ml} / \mathrm{l}$ dan $2,4 \mathrm{ml} / \mathrm{l}$ namun berbeda nyata dengan perlakuan kontrol $(0 \mathrm{ml} / \mathrm{l})$.

\section{DAFTAR PUSTAKA}

Ananta, E. N. R. (2017). Penggelondongan Ikan Bandeng (Chanos chanos) di Salinitas Payau Buatan. Laporan Proyek Mandiri (Unpublished). Politeknik Negeri Lampung. Bandar Lampung : 34 hal.

Aslianti, T., Nasukha, A. dan Setyadi, I. (2014). Perkembangan Tulang Belakang dan Aktivitas Enzim Protease Larva Ikan Bandeng, Chanos chanos Forsskal yang Dipelihara pada Media Berbeda. Jurnal Ilmu dan Teknologi Kelautan Tropis. Vol. 6 (1) : 87100.

Avnimelech, Y. (1999). Carbon/Nitrogen Ratio as Control Element in Aquaculture Systems. Aquaculture. Vol. 176 (3) : 227235.

De Schryver, P., Crab, R., Defoirdt, T., Boon, N., Verstraete, W. (2008). The Basics of Bioflocs Tecnology: The Added Value for Aquaculture. Aquaculture. Vol. 277 (3) : 125137.

Effendie, M.I. 1997. Biologi Perikanan. Yayasan Pustaka Nusatama. Yogyakarta : 163 hal.

Gede, I. P. dan Purwata, I. K. (2019). Pemanfaatan Gula Aren Original (Areo) Sebagai Bahan Olahan Produk Kuliner Lokal dalam Pengembangan Kewirausahaan Masyarakat Desa Kekait Kabupaten Lombok Barat. Open Journal System. Vol. 14 (1) : 1957 1962

Gustiana, B. 2018. Pengaruh Pemberian Molase pada Aplikasi Probiotik terhadap Pertumbuhan dan Kelangsungan Hidup Ikan Lele Sangkuriang (Clarias gariepinus). Skripsi. Universitas Sumatera Utara. Sumatera Utara : $83 \mathrm{hlm}$.

Mas'ud, F. (2011). Prevalensi dan Derajat Infeksi Dactylogyrus sp. Pada Insang Benih Bandeng (Chanos chanos) di Tambak Tradisional, 
Kecamatan Glagah, Kabupaten Lamongan. Jurnal Ilmiah Perikanan dan Kelautan. Vol. 3 (1): 27-39.

Mukhlis, A., Abidin, Z. dan Rahman, I. (2017). Pengaruh Konsentrasi Pupuk Ammonium Sulfat terhadap Pertumbuhan Populasi Sel Nannochloropsis sp. BioWallacea Jurnal Ilmiah Ilmu Biologi. Vol 3 (3) : 144-150

Ombong, F. dan Salindeho, I.R.N. (2016). Aplikasi Teknologi Bioflok (BFT) pada Kultur Ikan Nila, (Oreochromis niloticus). Budidaya Perairan. Vol. 4 (2): 16-25.

Pramono, T. B., Sukardi, P., Soedibya, P.H.T. dan Listiowati, E. (2019). Bioflok Lele. Penebar Swadaya. Jakarta : $76 \mathrm{hlm}$.

Romadon, A. dan Subekti, E. (2011). Teknik Budidaya Ikan Bandeng Di Kabupaten Demak. Mediagro. Vol. 7 (2) :19-24.

SNI. (2013). Ikan Bandeng (Chanos chanos, Forskal) - Bagian 3:
Produksi Benih. Badan Standarisasi Nasional. Jakarta: 13 hlm.

Supriyatna, A., Rochaniawan, D. dan Romdlianto, M. (2013). Penggunaan Tetes Tebu Pada Media Pemeliharaan Larva Ikan Bandeng (Chanos chanos Forsskal). Bul. Tek. Lit. Akuakultur. Vol. 11 (2) : 105-107.

Suwoyo, H.S., Mansyur, A. dan Gunarto. 2012. Penggunan Sumber Karbon Organik pada Budidaya Udang Vaname (Litopenaeus vannamei) dengan Tenologi Bioflok. Prosiding Indoaqua : 91-103.

Zulfahmi, I., Syahimi, M. dan Muliari. 2018. Pengaruh Penambahan Bioflok denga Dosis Berbeda Terhadap Pertumbuhan Benih Udang Windu (Penaeus monodon FABRICIUS 1798). Al-Kauniyah; Jurnal of Biology. Vol. 11 (1) : 18. 